\title{
Multivariate Analysis for Morphological Characteristics of N'Dama Cattle Breed in Two Agro-ecological Zones of Côte d'Ivoire
}

\author{
N'goran Kouame Edouard \\ Département Biochimie Génétique et Département de Biologie Animale de \\ l'UFR Sciences Biologiques, Université Peleforo Gon Coulibaly, \\ Korhogo, Côte d'Ivoire \\ Bamba Kalo Lacine \\ Kouassi N'Gouan Cyrille \\ Station d'Elevage du Centre National de Recherche Agronomique (CNRA) \\ Bouaké, Côte d'Ivoire

\section{Loukou N'Goran Etienne} \\ Département Biochimie Génétique de l'UFR Sciences Biologiques, \\ Université Peleforo Gon Coulibaly, Korhogo, Côte d'Ivoire

\section{Dayo Guiguigbaza-Kossigan \\ Sangare Mamadou \\ Yapi-Gnaore Chia Valentine} \\ Centre International de Recherche-Développement sur l'Élevage en zone \\ Subhumide (CIRDES), Bobo Dioulasso, Burkina Faso
}

Doi: 10.19044/esj.2018.v14n3p602 URL:http://dx.doi.org/10.19044/esj.2018.v14n3p602

\begin{abstract}
Information on morphological characteristics is a prerequisite to sustainable breed improvement, utilization, and conservation. In this study, 108 N'Dama cattle cows from 11 farms of central and northwestern regions of Côte d'Ivoire were described using visual appreciation criteria and linear body measurements. The variables were studied using principal component analysis (PCA) and discriminant analysis. Results indicated that the most common N'Dama is fauve $(83.33 \%)$ and it has straight back profile $(69.44 \%)$ and lyre horn $(74.07 \%)$. Agroecological zone has a significant $(\mathrm{p}<0.01)$ effect on linear body measurements of N'Dama. The central region animals had higher head width $(18.94 \pm 2.18 \mathrm{~cm})$, skull length $(22.51 \pm 2.18 \mathrm{~cm})$, skull width $(16.51 \pm$ $1.72 \mathrm{~cm})$, muzzle circumference $(40.83 \pm 2.58 \mathrm{~cm})$, distance between horns $(15 \pm 1.90 \mathrm{~cm})$, ear length $(17.46 \pm 2.57 \mathrm{~cm})$, chest length $(160.11 \pm 15.8 \mathrm{~cm})$, chest depth $(71.55 \pm 7.41 \mathrm{~cm})$, and body length $(125.13 \pm 12.22 \mathrm{~cm})$ than those of northwestern region N'Dama. Thus, their respective values were: $15.41 \pm$
\end{abstract}


$2.85 \mathrm{~cm}, 18.62 \pm 2.6 \mathrm{~cm}, 12.44 \pm 3.94 \mathrm{~cm}, 38.8 \pm 2.61 \mathrm{~cm}, 13.72 \pm 1.52 \mathrm{~cm}$, $16.41 \pm 1.61 \mathrm{~cm}, 143.84 \pm 8.35 \mathrm{~cm}, 65.25 \pm 4.1 \mathrm{~cm}$, and $119.18 \pm 12.38 \mathrm{~cm}$. PCA revealed that N'Dama morphometric variability performed from the 9 variables (Lt, lt, Lc, lc, pt, hg, Pth, Lcp and Lf) were more associated with the first two factors. In regards to the discriminant analysis, these 9 variables distinguished the N'Dama significantly $(\mathrm{p}<0.05)$ into two populations that corresponds with the two agroecological zones.

Keywords: N'Dama cattle, phenotypical, variability, description

\section{Introduction}

West Africa sub region were initially populated with the two subspecies of domestic cattle, Humpless Bos taurus and Humped Bos indicus and their crossbreds. Their progenitor is the wild auroch, Bos primigenius domesticated in southeastern of Asia, in Middle East (Edwards et al., 2007), that has gone into extinction today (Rokosvz', 1995). The archaeological and molecular data allows the making of inferences based on the history of African cattle, including their possible migration routes within the African continent (Epstein \& Mason, 1984; Hanotte et al., 2002; ILRI, 2006; Stock \& GiffordGonzalez, 2013). Among Humpless Bos Taurus, those that have longhorns, including N'Dama, might have been introduced first in Africa, followed by humpless shorthorns cattle about 2,500 years later (Epstein \& Mason, 1971; Rege, 1999). The presence of N'Dama breed in West African sub region would have been observed 5000 to $2350 \mathrm{BC}$ (Coulomb, 1976). Berber migrations of the $16^{\text {th }}$ century would favorably have an important nucleus setting up which would be fixed in Fouta Djallon highlands in Guinea. It is from this nucleus that the breed spread to the rest of West and Central Africa where it acquires unique evolutionary adaptation to harsh climate (Hansen, 2004) and various endemic diseases (Roberts \& Gray, 1973; Murray et al., 1984; 1990; Ngamuna et al., 1988; Claxton \& Leperre, 1991; Dwinger et al., 1992; Mottioli et al., 1995; Mottioli et al., 2000). However, N'Dama breed is small in size, and its productivity is lower compared to most of the zebu cattle populations in tropical areas (Rege, 1999; Okeyo, 2015).

However, most West and Central African countries, including Côte d'Ivoire, are faced with the demand for livestock products which is continuously increasing. Also, they make use of local breed, mainly N'Dama, in uncontrolled crossbreeding with various European or American improved cattle breeds and humpled zebus breeds. These crossbreeding took place mainly in the private farm or through the livestock development project in the central and north regions of Côte d'Ivoire (MIRAH, 2003; Eroarome, 2009). Thus, the structure of Ivoirian cattle remain largely unknown mainly when it has to do with the genetic distinctiveness of these cattle breeds (Sokouri et al., 
2007; 2009; N'Goran et al., 2008). The consequence is that this local cattle breed is facing a genetic erosion and loses its genetic ability in climate change context.

This paper focuses on describing the physical and morphological characteristics of the N'Dama breed in current climate change context of Côte d'Ivoire. This investigation remains an essential step for one of the best knowledge of animal genetic resource which, according to FAO (2012), is capital for zoogenetic resource management planning in local, national, regional, and world levels.

\section{Materials and Methods Study Area}

This study was conducted in six administrative localities including five (Bouaké, Brobo, Dimbokro, Toumodi and Yamoussoukro) in Central region and two (Ouaninou and Sipilou) in northwest region of Côte d'Ivoire (Figure 1). The Central region is located at $7^{\circ} 41^{\prime} 37^{\prime \prime}$ North latitude and $5^{\circ} 16^{\prime} 36^{\prime \prime}$ West longitude. The mean annual temperature and rainfall ranges from 14 to $39{ }^{\circ} \mathrm{C}$ and from 1200 to $1600 \mathrm{~mm}$, respectively. This central region has a tropical climate with four seasons: a long dry season from December to May, a short dry season from July to October, a long rainy season from May to July, and a short rainy season from October to November (Eroarome, 2009; http://www.atlapedia.com). The central region is covered by a pre-forest savannah with small trees broken by forest Island and with galleries of forest in the lowlands.

Northwest region is located at $7^{\circ} 55^{\prime} 0^{\prime \prime}$ North latitude and $8^{\circ} 4^{\prime} 60^{\prime \prime}$ West longitude. It has a sudano Guinean climate characterized by a mean annual temperature and rainfall that ranges from 20 to 26 and from 1127 to $2400 \mathrm{~mm}$, respectively. This climate has two vegetation, including a dense forest and transitional vegetation between forest and savannah. In addition, it has two seasons: a long wet season from April to October and a dry season from November to March (Viennot, 1983; Eroarome, 2009; http://www.atlapedia.com).

\section{Farm Sampling}

The sampling frame was established following an exploratory survey to all five great livestock regions (North, Central, West and East) of Côte d'Ivoire and the discussions with local livestock extension officers and researchers. The discussion aimed to identify the regions where we can find the pure N'Dama breed. Based on these discussions, two great regions have been selected: the northwest regions which border the original breeding area (Fouta Djallon highlands in Guinea) of the Guinean N'Dama type and the Central region, where N'Dama breeding have been developed through the 
different national livestock project such as SODEPRA (MIRAH, 2003; Eroarome, 2009). The objective being to describe the pure N'Dama breed, 11 farms that keeps pure N'Dama breed, and not using other cattle breed in their reproduction system were purposely retained. In these farms, the herd size varies from 15 to 50 animals and they were raised on fenced natural pastures where they graze day and night or are herded by day and kept in pens at night. The animals have access to mineral salt licks and are dipped or sprayed 2 to 4 times a month.

\section{Data Collection}

Data on the assessment of qualitative and quantitative morphological traits were obtained from 108 N'Dama cows from November 2016 to April 2017 on 11 traditional farms. Only the animals aged three years and above were considered for the purpose of uniformed comparison. The FAO (2012) qualitative and quantitative cattle breed descriptor list was followed to characterize the animals physically and morphologically. The animals were described individually in their respective farm. The qualitative characters such as ear orientation, eyelid colour, muzzle colour, coat colour, back profile, horn orientation, and dewlap development were recorded based on subjective visual observation.

The quantitative morphometrical characters were obtained by measuring tape calibrated in centimeters $(\mathrm{cm})$ after restraining and holding the animals in an unforced position. All measurements were taken by the same personnel team on all farms. The following linear body measurements were taken: head length (Lt), head width (lt), skull length (Lc), skull width (lc), muzzle length ( $\mathrm{Lf})$, muzzle circumference (cfm), horn length (Lco), distance between horns (dbb), ear length (Lo), chest length (pt), tail length (Lq), height at wither (hg), chest depth (Pth), and body length (Lcp). The age of the animals was estimated using dentition method as suggested by Charray et al. (1992).

\section{Statistical Analysis}

Descriptive statistics were used to analyze phenotypic characterization data. Discrete measurement based on the form and appearance of the investigated animals were analyzed using the frequency procedure of chisquare test at the $95 \%$ confidence level. Quantitative linear body measurements were analyzed using the generalized linear model procedures. Agro-ecological zones were fitted as fixed independent variables, whereas linear body measurements were fitted as dependent variables. Thus, agroecological effects on body measurements were assessed using the ANOVA. Means were separated using Duncan's multiple range test procedure and values were considered significant at $\mathrm{p}<0.05$. The major quantitative morphological variable included in phenotypical variability and Pearson's 
coefficients of correlation (r), among the various variables, were estimated. This was later used for the principal component factor analysis (PCA). The discriminant quantitative variable and Mahalanobis distance between both N'Dama populations of agro-ecological zones were assessed using discriminant analysis. All analysis were done using XLSTAT 2015.4.01.


Figure 1. Study area 


\section{Results \\ Phenotypic Characterization Qualitative Characters}

The results relating to the qualitative characters in all female N'Dama raised in the two agro-ecological zones (Central savannah and northwest forest regions) are presented in Table 1.

Table 1. Percentage values for some phenotypic qualitative traits observed in N'Dama breed of two agro-ecological zones

\begin{tabular}{|c|c|c|c|c|c|c|c|}
\hline \multirow{4}{*}{ Characters } & \multirow{4}{*}{ Trait } & \multirow{3}{*}{\multicolumn{2}{|c|}{$\begin{array}{l}\text { two agro-ecological Z } \\
\text { Central savannah } \\
\text { region: } \\
\text { Zone } 1(47) \\
\end{array}$}} & & & & \\
\hline & & & & \multicolumn{4}{|c|}{ Northwest forest } \\
\hline & & & & \multicolumn{4}{|c|}{$\begin{array}{l}\text { region: Zone } 2 \text { Total } \\
(61)\end{array}$} \\
\hline & & $\overline{\mathrm{N}}$ & $\%$ & $\mathrm{~N}$ & $\%$ & $\mathrm{~N}$ & $\%$ \\
\hline \multirow{2}{*}{ Ear orientation } & Horizontal & 35 & 74.47 & 58 & 95.08 & 93 & 86.11 \\
\hline & Erect & 12 & 25.53 & 3 & 4.92 & 15 & 13.89 \\
\hline \multirow{2}{*}{ Eyelid colour } & Unpigmented & 47 & 100 & 39 & 63.93 & 86 & 79.63 \\
\hline & Pigmented & 0 & 0 & 22 & 36.07 & 22 & 20.37 \\
\hline \multirow{2}{*}{ Muzzle colour } & Unpigmented & 31 & 65.96 & 37 & 60.66 & 68 & 62.96 \\
\hline & Pigmented & 16 & 34.04 & 24 & 39.34 & 40 & 37.04 \\
\hline \multirow{4}{*}{ Coat colour } & Fauve & 39 & 82.98 & 51 & 83.61 & 90 & 83.33 \\
\hline & Black & 2 & 4.25 & 1 & 1.64 & 3 & 2.78 \\
\hline & Pi-red & 6 & 12.77 & 7 & 11.48 & 13 & 12.04 \\
\hline & Greyish-black & 0 & 0 & 2 & 3.28 & 2 & 1.85 \\
\hline \multirow{3}{*}{ Back profile } & Straight & 31 & 65.96 & 44 & 72.13 & 75 & 69.44 \\
\hline & Concave & 4 & 8.51 & 13 & 21.31 & 17 & 15.74 \\
\hline & Convex & 12 & 25.53 & 4 & 6.56 & 16 & 14.81 \\
\hline \multirow{3}{*}{ Horn orientation } & Lyre & 35 & 74.47 & 45 & 73.77 & 80 & 74.07 \\
\hline & Increasing & 10 & 21.28 & 12 & 19.67 & 22 & 20.37 \\
\hline & Crown & 2 & 4.25 & 4 & 6.56 & 6 & 5.56 \\
\hline \multirow[b]{2}{*}{ Dewlap } & Low developed & 22 & 46.81 & 16 & 26.23 & 38 & 35.19 \\
\hline & $\begin{array}{l}\text { Moderately } \\
\text { developed }\end{array}$ & 25 & 53.19 & 45 & 73.77 & 70 & 64.81 \\
\hline
\end{tabular}

Data presented in this table showed combined results of the major qualitative characters of both agro-ecological zones animals. The observed combination of coat colour of the N'Dama in both agroecological zones were fauve $(83.33 \%)$, black $(2.78 \%)$, pi-red $(12.04 \%)$, and greyish-black $(1.85 \%)$ (Figure 2). The dominant back profile of N'Dama breed in the agro-ecological zone (central region) was straight $(65.96 \%)$, followed by convex $(25.53 \%)$ and concave $(8.51 \%)$. The back profile of most N'Dama $(72.13 \%)$ of zone 2 (North-West region) was straight, whereas the rest was concave $(21.31 \%)$ and convex $(6.56 \%)$. The dewlap was low developed for $35.19 \%$ of the animals, whereas it was moderately developed for the rest. Most of N'Dama in the study zones had horizontal $(86.11 \%)$ and erect $(13.89 \%)$ ear. These animals have lyre (74.07\%) (Figure 2), increasing (20.37\%), and crown (5.56\%) horn. Most 
of the animals had unpigmented muzzle (62.96\%) and eyelid (79.63\%) versus pigmented muzzle (37.04\%) and eyelid (20.37\%).

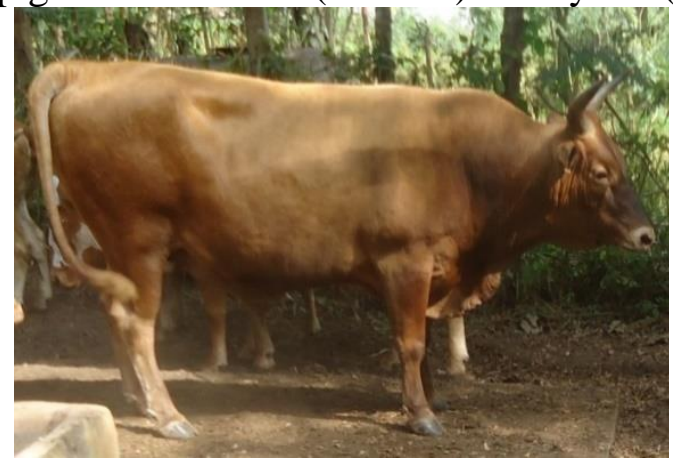

A) N’Dama from Bouaké (Brobo)

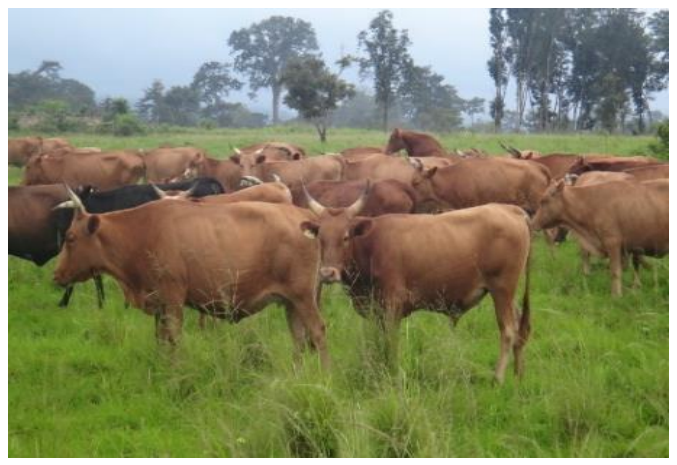

C) N'Dama flock from Yamoussoukro

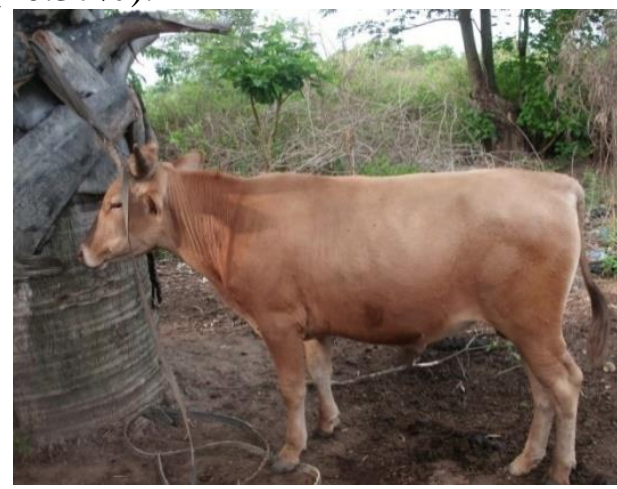

B) N'Dama from Ouaninou

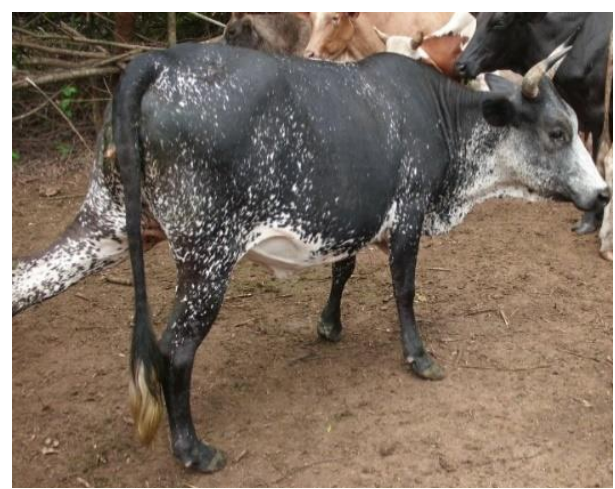

D) N'Dama from Sipilou

A and C: N'Dama from Central region, B and D: N'Dama from the Northwest region

Figure 2. N'Dama animals from Central and northwest regions of Côte d'Ivoire

\section{Morphometrical Characterization} Arithmetic Means and Agro-ecological Zone Effect

Arithmetic and least-squares means for body measurements are presented in Table 2.

Table 2. Average values $(\mathrm{cm})$ of quantitative morphometrical traits of N'Dama animals

\begin{tabular}{|c|c|c|c|c|c|c|c|}
\hline \multirow[b]{3}{*}{$\begin{array}{l}\text { Morphometrical } \\
\text { traits }(\mathrm{cm})\end{array}$} & \multicolumn{4}{|c|}{$($ means $\pm \mathrm{SD} ; \mathrm{N}=108)$} & \multirow[b]{3}{*}{$\begin{array}{l}\text { Overall means } \\
(\mathrm{n}=108)\end{array}$} & \multirow{2}{*}{\multicolumn{2}{|c|}{ Zone effect }} \\
\hline & Zone1 $(n=44)$ & & Zone2 $(n=64)$ & & & & \\
\hline & $\mathrm{M} \pm \mathrm{SD}$ & $\begin{array}{l}\mathrm{CV} \\
(\%)\end{array}$ & $\mathrm{M} \pm \mathrm{SD}$ & $\begin{array}{l}\mathrm{CV} \\
(\%)\end{array}$ & & $\begin{array}{l}\text { Fisher } \\
\text { Test }\end{array}$ & SIG \\
\hline Hea & $44.94 \pm 2.91$ & 6.49 & $44,97 \pm 4.27$ & 9.5 & 44.9 & 0.002 & NS \\
\hline Head width (lt) & $18.94^{\mathrm{a}} \pm 2.18$ & 11.52 & $15.41^{b} \pm 2.85$ & 18.52 & $16.94 \pm 3.11$ & 49.453 & $* *$ \\
\hline Skull length (Lc) & $22.51^{\mathrm{a}} \pm 2.18$ & 9.67 & $18.62^{b} \pm 2.60$ & 13.97 & $20.31 \pm 3.09$ & 68.149 & $* *$ \\
\hline
\end{tabular}




\begin{tabular}{|c|c|c|c|c|c|c|c|}
\hline Skull width (lc) & $16.51^{\mathrm{a}} \pm 1.72$ & 10.40 & $12.44^{\mathrm{b}} \pm 3.94$ & 31.66 & $14.21 \pm 3.75$ & 43.651 & $* *$ \\
\hline Muzzle length (Lf) & $22.62^{\mathrm{b}} \pm 2.44$ & 10.77 & $24.9^{\mathrm{a}} \pm 3.01$ & 12.11 & $23.91 \pm 2.99$ & 17.944 & $* *$ \\
\hline $\begin{array}{l}\text { Muzzle } \\
\text { circumference }(\mathrm{cfm})\end{array}$ & $40.83^{a} \pm 2.58$ & 6.32 & $38.8^{b} \pm 2.61$ & 6.72 & $39.69+2.77$ & 16.179 & $* *$ \\
\hline Horn length (Lco) & $27.51 \pm 6$ & 21.80 & $29.2 \pm 5.94$ & 20.33 & $28.45 \pm 5.99$ & 142 & NS \\
\hline $\begin{array}{l}\text { Distance between } \\
\text { horns }(\mathrm{dbb})\end{array}$ & $15^{\mathrm{a}} \pm 1.90$ & 12.66 & $13.72^{b} \pm 1.52$ & 11.06 & $14.28 \pm 1.80$ & 15.121 & $* *$ \\
\hline Ear length (Lo) & \pm 2.57 & 14.74 & $16.41^{b} \pm 1.61$ & 9.83 & & &  \\
\hline Ches & $\mathrm{a} \pm 15.80$ & 9.87 & $143.84^{\mathrm{b}} \pm 8.35$ & 5.81 & 4.56 & 47.529 & $* *$ \\
\hline h (Lq) & $75.45^{b} \pm 6.43$ & 8.52 & $79.11^{\mathrm{a}} \pm 8.99$ & 11.36 & $77.51 \pm 8.15$ & 5.585 & $*$ \\
\hline wither (hg) & $109.28 \pm 8.01$ & 7.33 & $111.61 \pm 6.66$ & 5.97 & $110.59 \pm 7.33$ & 2.721 & NS \\
\hline Chest & $71.55^{\mathrm{a}} \pm 7.41$ & 10.35 & $65.25^{\mathrm{b}} \pm 4.10$ & 6.28 & $67.99 \pm 6.54$ & 31.703 & $* *$ \\
\hline Body length (Lcp) & $125.13^{\mathrm{a}} \pm 12.22$ & 9.77 & $119.18^{b} \pm 12.38$ & 10.39 & $121.77 \pm 12.61$ & 6.195 & * \\
\hline
\end{tabular}

${ }^{a, b}$ Means across column between zones with different superscript letters are significantly $(P<0,05)$ different. $M=$ Means, $S D=$ Standard Deviation, $C V=$ Coefficients of Variation, zone1 = agro ecological zone of savannah regions (center of Côte d'Ivoire), zone $2=$ agro ecological zone of forest regions (north-west of Côte d'Ivoire), SIG = Signification level: NS $=$ Not Significant; $* p<0.05 ; * * p<0.01 ; * * * p<0.001$.

Except for Lt, Lco and hg, the agro-ecological zone had a significant effect $(\mathrm{p}<0.05)$ on the quantitative linear body measured. This shows certain heterogeneity among the N'Dama cattle of the two agro-ecological zones. Animals of agro-ecological zone 1 had the highest values for the morphometrical traits except Lf and Lq.

\section{Multivariate Analysis}

Principal Component Analysis (PCA)

Pearson's correlation coefficients between all pairs of the various body traits of N'Dama cattle associated with PCA are shown in Table 5. 
Table 3. Pearson's correlations among measurements of N'Dama populations

\begin{tabular}{|c|c|c|c|c|c|c|c|c|c|c|c|c|c|c|}
\hline & $\mathrm{Lt}$ & $\mathrm{Lt}$ & $\mathrm{Lc}$ & lc & $\mathrm{Lf}$ & $\mathrm{cfm}$ & Lco & $\mathrm{dbb}$ & Lo & $\mathrm{pt}$ & $\mathrm{Lq}$ & hg & Pth & Lcp \\
\hline $\mathrm{Lt}$ & 1 & & & & & & & & & & & & & \\
\hline lt & 0,536 & 1 & & & & & & & & & & & & \\
\hline $\mathrm{Lc}$ & 0,351 & 0,662 & 1 & & & & & & & & & & & \\
\hline lc & 0,476 & 0,847 & 0,656 & 1 & & & & & & & & & & \\
\hline $\mathrm{Lf}$ & 0,647 & 0,255 & $-0,017$ & 0,220 & 1 & & & & & & & & & \\
\hline $\mathrm{cfm}$ & 0,229 & 0,364 & 0,319 & 0,219 & 0,055 & 1 & & & & & & & & \\
\hline Lco & 0,310 & 0,138 & 0,120 & $-0,036$ & $\mathbf{0 , 3 2 7}$ & 0,268 & 1 & & & & & & & \\
\hline $\mathrm{dbb}$ & 0,120 & 0,174 & 0,309 & 0,156 & $-0,198$ & 0,322 & $-0,126$ & 1 & & & & & & \\
\hline Lo & 0,139 & 0,068 & 0,344 & 0,043 & $-0,082$ & 0,038 & 0,097 & 0,245 & 1 & & & & & \\
\hline $\mathrm{pt}$ & 0,251 & 0,446 & 0,480 & $\mathbf{0 , 2 7 3}$ & 0,046 & 0,436 & 0,213 & 0,242 & 0,325 & 1 & & & & \\
\hline $\mathrm{Lq}$ & 0,447 & 0,116 & 0,133 & 0,081 & 0,512 & 0,123 & 0,241 & 0,197 & 0,276 & 0,183 & 1 & & & \\
\hline hg & 0,320 & 0,172 & 0,084 & 0,115 & $\mathbf{0 , 5 0 7}$ & $-0,043$ & 0,251 & 0,086 & 0,125 & 0,334 & 0,512 & 1 & & \\
\hline Pth & 0,387 & 0,598 & 0,518 & 0,423 & 0,201 & 0,423 & 0,279 & 0,162 & 0,279 & $\mathbf{0 , 8 2 7}$ & 0,208 & 0,291 & 1 & \\
\hline Lcp & 0,470 & 0,518 & 0,430 & 0,481 & 0,382 & 0,152 & 0,245 & 0,137 & 0,226 & 0,543 & 0,343 & 0,591 & 0,500 & 1 \\
\hline
\end{tabular}

Lt = Head length, $l t=$ Head width, Lc = Skull length, $l c=$ Skull width, $L f=$ Muzzle length, $c f m=$ Muzzle circumference, Lco $=$ Horn length, dbb $=$ distance between horns, Là = Ear length, pt = Chest length, Lq = Tail length, $h g=$ Height at wither, Pth $=$ Chest depth, Lcp = Body length Bold values are significant to the threshold of $5 \%(p<0,050)$.

Lt, pt, Pth and Lcp were significantly and positively correlated with the other morphometrical traits except for $\mathrm{dbb}$ and Lo for Lt, Lf for $\mathrm{pt}$, dbb for Pth, and cfm and dbb for Lcp. In addition, hg was significantly correlated with Lf, Lco, pt, and Lq. Significant correlation was found between Lq and Lf, Lco and Lo. Morphometrical trait dbb was significantly correlated with Lc, cfm, Lo and Lq positively, but was negatively correlated with Lf. Significant and positive correlations were found between It and Lc, lc, Lf and cfm. Furthermore, there were significant positive correlation between Lc, lc, cfm, and lo. Morphometrical trait lc was correlated significantly and positively with Lf and cfm, whereas Lf was correlated with Lco, Lq, and hg. Significant correlation was found between cfm and Lco. 
Results of the factor pattern and communality of the body measurements of N'Dama cattle breed were reported in Table 4. The KaiserMeyer measure of Sampling Adequacy, which determines the proportion of the variance in difference measurements caused by underlying factors, was equal to 0.75 . Five factors with eigenvalues superior to 1 were extracted (Table 4). They explained $77.45 \%$ of the total variance. The first factor explained $35.67 \%$ of variability, and loadings were highest for Lt, lt, Lc, lc, pt, hg, Pth, and Lcp. The second factor described $15.28 \%$ of the total variability, and loadings were highest for Lf, Lq, and hg. Factor three represented $10.70 \%$ of variability. It was represented by significant negative and positive high loadings lc and Lo respectively. The morphometrical traits $\mathrm{cfm}$ and Lco were more associated with the fourth factor that describes $8.48 \%$ of variability. The fifth factor accounted for $7.31 \%$ of variance, and loading was highest for $\mathrm{dbb}$.

Likewise, variables' communalities, which represent the proportion of variance of each of the 14 variables shared by all the remaining body measurements, were medium to high. However, they varied from 0.547 to 0.869 (Table 4).

Table 4. Eigenvalues and percent of total variance along with factor loadings and communalities of the body measurements of two N'Dama cattle breed populations

\begin{tabular}{lllllll} 
Variables & $\mathrm{F}_{1}$ & $\mathrm{~F}_{2}$ & $\mathrm{~F}_{3}$ & $\mathrm{~F}_{4}$ & $\mathrm{~F}_{5}$ & Communality \\
\hline $\mathrm{Lt}$ & $\mathbf{0 , 7 0 1}$ & 0,323 & $-0,251$ & $-0,062$ & 0,287 & 0,812 \\
$\mathrm{lt}$ & $\mathbf{0 , 7 8 7}$ & $-0,271$ & $-0,440$ & $-0,021$ & $-0,005$ & 0,818 \\
$\mathrm{Lc}$ & $\mathbf{0 , 6 9 6}$ & $-0,458$ & $-0,079$ & $-0,142$ & $-0,027$ & 0,869 \\
$\mathrm{lc}$ & $\mathbf{0 , 6 7 5}$ & $-0,285$ & $\mathbf{- 0 , 5 5 5}$ & $-0,239$ & $-0,008$ & 0,729 \\
$\mathrm{Lf}$ & 0,459 & $\mathbf{0 , 7 4 0}$ & $-0,268$ & 0,034 & 0,137 & 0,647 \\
$\mathrm{pt}$ & $\mathbf{0 , 7 1 2}$ & $-0,253$ & 0,358 & 0,241 & $-0,295$ & 0,713 \\
$\mathrm{Lq}$ & 0,475 & 0,528 & 0,317 & $-0,251$ & 0,319 & 0,794 \\
hg & $\mathbf{0 , 5 0 8}$ & $\mathbf{0 , 5 6 4}$ & 0,229 & $-0,202$ & $-0,234$ & 0,707 \\
Pth & $\mathbf{0 , 7 8 5}$ & $-0,200$ & 0,145 & 0,278 & $-0,236$ & 0,791 \\
Lcp & $\mathbf{0 , 7 6 5}$ & 0,170 & 0,016 & $-0,150$ & $-0,304$ & 0,857 \\
cfm & 0,461 & $-0,310$ & 0,122 & $\mathbf{0 , 5 0 6}$ & 0,496 & 0,690 \\
Lco & 0,364 & 0,362 & 0,160 & $\mathbf{0 , 6 0 9}$ & 0,052 & 0,649 \\
dbb & 0,294 & $-0,385$ & 0,392 & $-0,363$ & $\mathbf{0 , 5 1 6}$ & 0,547 \\
Lo & 0,332 & $-0,139$ & $\mathbf{0 , 5 9 9}$ & $-0,293$ & $-0,124$ & 0,688 \\
Eigenvalue & 4,99 & 2,13 & 1,49 & 1,18 & 1,02 & \\
\% of total variance & 35.67 & 15.28 & 10.70 & 8.48 & 7.31 & \\
& & & & & & \\
\hline
\end{tabular}

$L t=$ Head length, $l t=$ Head width, $L c=$ Skull length, $l c=$ Skull width, $L f=$ Muzzle length, $c f m$ $=$ Muzzle circumference, Lco $=$ Horn length, $d b b=$ distance between horns, Lo = Ear length, $p t=$ Chest length, $L q=$ Tail length, $h g=$ Height at wither, Pth = Chest depth, Lcp = Body length. Bold values are more associated with the factor. 




Figure 3. Scree plot of factor analysis for body measurements of N'Dama cattle breed

Animals' plot in bi-dimensional presentation $\left(\mathrm{F}_{1}-\mathrm{F}_{2}\right)$, according to PCA accounting for $50.96 \%$ of the total variability, explains better the N'Dama phenotypical variability. It separates the animals into two groups (Figure 4).

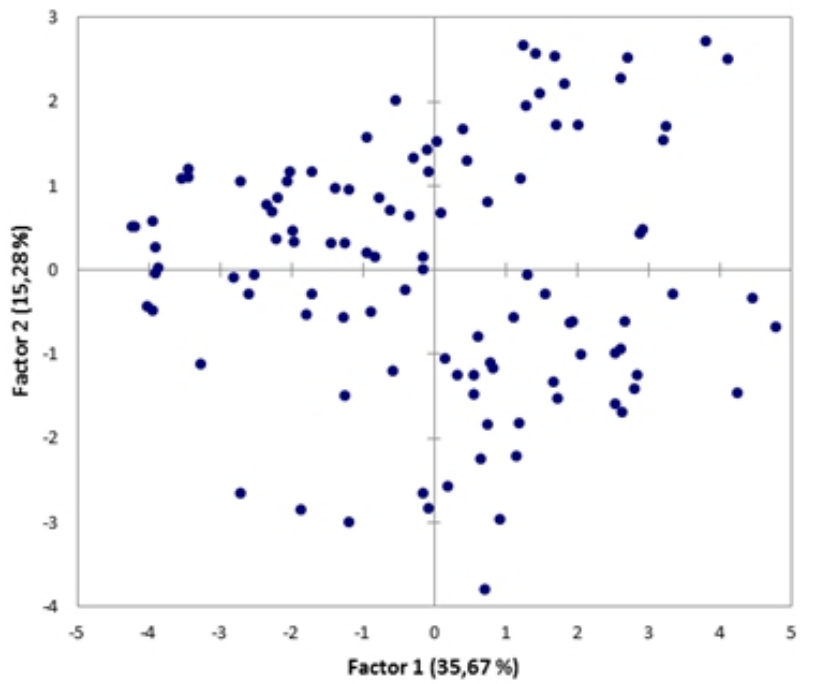

Figure 4. Bi-dimensional representation of individuals of the two agro-ecological zones N'Dama according to PCA for the quantitative traits

\section{Discriminant Analysis}

Discriminant Analysis aims to specify PCA results. Then, it was performed from the 9 variables (Lt, lt, Lc, lc, pt, hg, Pth, Lcp and Lf), which were more associated with the two first factors according to PCA. These measurements were the explicative variables, whereas agro-ecological zones 
were the independent variables. Discriminant analysis which generated only one discriminant function explained $100 \%$ of the animal phenotypical variability; in other words, the 9 measurements had the most discriminant power. Therefore, Lt, lt, Lc, lc, pt, hg, Pth, Lcp, and Lf may be used to differentiate between both populations. The confusion matrix (Table 5) shows that $96.30 \%$ of the animals are correctly classified, and only $4.7 \%$ are reclassified. Moreover, the Mahalanobis pairwise distance between the two populations of N'Dama was equal to 3.69, which is significant ( $<<0.05)$. Also, discriminant analysis shows that N'Dama populations are separated following the two agro-ecological zones (Figure 5).

Table 5. Percentage of animal correctly or incorrectly classified in respect to agro-ecological

\begin{tabular}{lllll} 
& \multicolumn{4}{c}{ zones } \\
\cline { 2 - 5 } Aminal & ND1 & ND3 & Total & \% correct \\
\hline ND1 & 44 & 3 & 47 & 93.62 \\
ND3 & 1 & 60 & 61 & 98.38 \\
Total & 45 & 63 & 108 & 96.30 \\
\hline
\end{tabular}

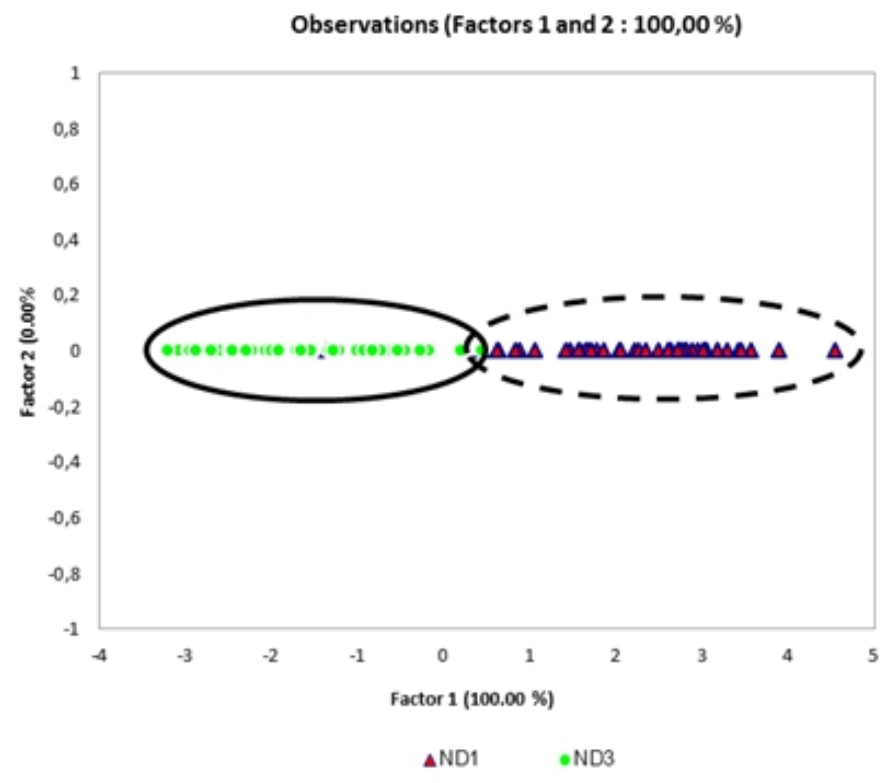

Figure 5. Discriminant Analysis for individuals body measurements of the two agroecological zones N'Dama populations

\section{Discussion}

In the present study, N'Dama cattle breed showed a variety of coat colours (fauve, black, pie-red and greyish-black). The dominant coat colour, horn orientation, and back profile of these N'Dama animals were fauve, lyre horn $(74.07 \%)$ and straight back profile $(69.44 \%)$. The fauve coat colour associated with the horn in lyre and straight back profile are the physical 
characteristics of the N'Dama breed reported by Doutressoulle (1946), Larrat et al. (1948), Coulomb (1976), and Akouango et al. (2010) in West and central African sub region. Based on the study of several authors including Epstein (1971), Coulomb (1976) and Pagot (1985), the origin of N'Dama is located in the Fouta Djallon highlands of Guinea. It is from here the N'Dama spread to the rest of West and Central Africa where it acquired an adaptation to the climates of respective regions (Touré \& Hoste, 1987; D’Ieteren, 1994; Epstein \& Mason, 1984; Rege \& Tawah, 1999; Hanotte et al., 2002) and it is known by different names. Other names for them include Boyenca (Guinea-Bissau), Fouta Jallon, Fouta Longhorn, Fouta Malinke, Mandingo (Liberia) or N'Dama Petite (Senegal).

The variety of N'Dama coat colour observed in this study could be one of the consequences of the N'Dama adaptation to Ivoirian environment as it has been already reported by Khan et al. (2013) for the buffaloes in Pakistan, Katongole et al. (1994) for the sheep in Botwana, Mani et al. (2014) for the goat in Niger, and Epstein and Mason (1984) in Africa and Saleem et al. (2013) in Pakistan for the cattle breeds.

The effect of the agro-ecological zone was not significant on Lt, Lco and hg, but was significant on the other traits (11), suggesting that morphological measurements of the two agro-ecological zones N'Dama populations are different from each other. The 11 morphological measurements variations across the two agro-ecological zones, with higher values being recorded among the animals reared in the savannah region (agroecological zone of central region), may be attributed to favourable prevailing circumstances in this region. Therefore, the breeding area had a great impact on the morphological measurements of Ivoirian N'Dama populations. This result is in agreement with that of Chencha et al. (2013) and Hanga et al. (2012), Dekhili et al. (2013), and Hilal et al. (2013; 2016) who confirmed that the morphological measurements variability are due to varied raising environment for the cattle in Ethiopia and the goat breeds in Ghana, Algeria and Morocco respectively.

In this study, the head length (Lt) and height at wither (hg) of the both agro ecological zones N'Dama are in the range of those obtained by Coulomb (1976) in CRZ Bouaké (44.8 $\pm 0.8 \mathrm{~cm}$ and $113.6 \pm 0.8 \mathrm{~cm}$ respectively). The chest girth (pt) measured in the savannah region (zone 1) and the muzzle length (Lf) measured in the forest region (zone 2) are in agreement with those reported by Coulomb (1976) in CRZ Bouaké (156.2 $\pm 1.8 \mathrm{~cm}$ and $23.8 \pm 0.4$ $\mathrm{cm}$ respectively). Nevertheless, the height wither (hg) found in the present study is similar to the value obtained by Akouango et al. (2010) for the N'Dama $(111.8 \pm 0.9 \mathrm{~cm})$ in RDC, whose chest girth $(144.4 \pm 1.3 \mathrm{~cm})$ is comparable with the N'Dama of forest region (zone 2). The height wither found in the study is higher than that reported by Choquet $(1969)(104 \mathrm{~cm})$. 
Correlations among morphological measurements of these N'Dama populations were, in general, positive and high, indicating a good association between these measurements. The positive significant correlation coefficient between large morphological measurements indicates that N'Dama populations of the savannah and forest regions of Côte d'Ivoire are very harmoniously conformed, reflecting balanced physical development (growth), and it also reveals that the populations have adapted to their respective environmental conditions.

Also, the high correlations among traits found in the current study highlighted the appropriateness of multivariate analyses.

The factor analysis showed that five factors explained $77.45 \%$ of total variance in N'Dama population. These proportions are the range of those reported by N'Goran et al. (2008) $(75.72 \%)$ on the dairy crossbreeds cows in three regions of Côte d'Ivoire (central, central west and south). However, the proportions of the present study are lower than those obtained by Sokouri et al. (2007) for various cattle breeds and crossbreds (N'Dama, zebu, méré and various crossbreds) population in Bouaké (96.9 \%) and Korhogo (95.7\%) areas. The communalities found in this current study showed that all the morphological measurement had high loadings on factor 1 , which is a good descriptor of general body size. On the other hand, factors 2, 3, 4, and 5 seemed to reflect the head shape for the both agro ecological zones N'Dama populations.

The most discriminant variables selected through the Principal Component Analysis (PCA) were Lt, lt, Lc, lc, Lf, pt, hg, Pth, and Lcp. The nine (9) morphological measurements can be useful to describe the variability of the both agro ecological zones N'Dama population. As a result, the six (6) other body measurements had limited differentiation effects and hence might not be trusted in studying morphological studies to define the breed characterization of this N'Dama population. Some of the discriminating variables (Lcp, pt and Lf) obtained in this study were similar to those obtained by N'Goran et al. $(2008 ; 2015)$ on the dairy cattle crossbreds in three regions of Côte d'Ivoire. However, Sokouri et al. (2007) reported that hump existence, body colour, pth, and hg would be very important in the differentiation of the N'Dama, Baoulé and zebu cattle breeds and various cattle crossbreds in Bouaké and Korhogo areas. Also, N'Goran et al. (2008) showed that the age at first calving, milk yield/day, Lcp, pt, and Lf had largest discriminant value for the dairy cattle crossbreds in central, central west and south regions in Côte d'Ivoire.

Based on the discriminant analysis, the nine (9) morphological measurements (Lt, lt, Lc, lc, Lf, pt, hg, Pth and Lcp) generated by PCA, had one of the most discriminant power in the differentiarion of the N'Dama populations of the both agro ecological zones. However, N'Goran et al. (2015) 
found that Lcp, pt, and Lf are important in the differentiation of the three dairy cattle crossbreds ( $F_{1}$ N'Dama x Abondance, $F_{1}$ N'Dama x Montbéliarde, and $\mathrm{F}_{1}$ N'Dama x Montbéliarde x Montbéliarde) in the south of Côte d'Ivoire. The Mahalanobis distance between the two populations was 3.69, indicating that a morphological differentiation between the two N'Dama populations is not too great. The result is in the range of this one found between $F_{1}$ N'Dama $x$ Abondance and $F_{1} N^{\prime}$ Dama $x$ Montbéliarde (3.58), but it is lower than the distance separating the Montbéliarde $\mathrm{x}\left(\mathrm{F}_{1} \mathrm{~N}^{\prime}\right.$ Dama $\mathrm{x}$ Montbéliarde) of $\mathrm{F}_{1}$ N'Dama $x$ Montbéliarde (8.53) and of $F_{1} N^{\prime}$ Dama $x$ Abondance (9.11) (N'Goran et al., 2015). This differentiation found in the present study may be due to two factors. The genetic exchange that took place between the central regions N'Dama with various improved cattle breeds through private farms and the livestock projects (MIRAH, 2003; N'Goran et al., 2008; 2017; Sokouri et al., 2009) could explain their great size compared with the northwest regions N'Dama size. The distinction between the two N'Dama populations may be due to the difference in climatic parameters between the central (savannah) and northwest (forest) regions.

The discriminant analysis showed a low misclassification error of individuals belonging to N'Dama populations of savannah and forest regions $(4.7 \%)$. This confirms that the N'Dama populations of the both agroecological zones are different from each other.

\section{Conclusion}

The results of this study revealed that the morphological measurements variations among two N'Dama populations corresponds to two agro ecological zones of Côte d'Ivoire. The N'Dama populations in the different studied areas have developed varied morphologically adaptable characteristics in their respective environment. Regarding quantitative traits such as Head width (lt), Skull length (Lc), Muzzle circumference (cfm), distance between horns (dbb), Ear length (Lo), Chest girth (pt), Chest depth (Pth) and body length (Lcp), savannah region N'Dama had significantly higher values than forest region N'Dama. The observed results could be complimented by molecular characterization which specifies the N'Dama genetic status in Côte d'Ivoire for the design of this cattle breed management and conservation strategies.

\section{Acknowledgements}

The authors would like to thank UEMOA and CORAF/WECARD for their financial support provided for the PROGEVAL project. They would like acknowledge CNRA-Bouaké, Université Peleforo Gon Coulibaly- Korhogo of Côte d'Ivoire, for their co-operation and scientific and technological inputs. The authors also wish to thank PROGIRS (Integrated Ranch and Station Management Project), local livestock extension officers and researchers, and 
the private farmers for their cooperation during the data collection process for the study.

\section{References:}

1. Akouango, F., Ngokaka C., Ewomango P. \& Kimbembe, E. (2010). Caractérisation morphométrique et reproductive des taureaux et vaches N'Dama du Congo. Animal Genetic Resources information. (46): 4147. DOI: https://doi.org/10.1017/S2078633610000688.

2. Charray, J., Humber, J.M. \& Leif, J. (1992). Manual of sheep production in the humid tropics of Africa. CAB International, Wallingford, UK.

3. Chencha Chebo., Workneh Ayalew \& Zewletaw (2013). On-farm phenotypic characterization of indigenous cattle populations of Gomo Goffa zone, Southern Ethiopia. Animal Genetic Resources information. (52): 71-82. Doi: 10.107/8207863361200046X.

4. Choquet, P. (1969). Intérêt et utilisation des bovins trypanotolérants. Thèse Doct vet. Alfort, 1969, $\mathrm{n}^{\circ} 22 ; 175 \mathrm{p}$.

5. Claxton, J. and Leperre, P. (1991). Parasite burdens and host susceptibility of Zebu and N'Dama cattle in village herds in Gambia. Veterinary Parasitology. 40:293-304.

6. Coulomb, J. (1976). La race N'Dama. Quelques caractéristiques zootechniques. Rév. Elev. Méd. Pays Trop., 29 (4): 367-380.

7. D'Ieteren, G.D.M. (1994). Trypanotolerant livestock, a sustainable option for increasing livestock production in tsetse affected areas. In: Rowlands, GJ and Teale, AJ (Editors), Towards increased Use of trypanotolerance: Current Research and future options. Proceedings of a Workshop organised by ILRAD an ILCA, Nairobi, Kenya: 3-14.

8. Dekhili, M., Bounechada, M. \& Mannalah, I. (2013). Multivariate analysis of morphological traits in Algerian goats, Sétif, North-Eastern Algeria. Anim. Genet. Res., 52 : 51-57.

9. Doutressoulle, G. (1946). Zootechnie et industrie animale en Afrique occidentale française. Ec. Afric. Méd. Vét., Bamako, Mali : 142p.

10. Dwinger, R.H., Clifford, D.J., Agyemang, K., Gettinby, G., Grieve, A.S., Kora, S. \& Bojang, M.A. (1992). Comparative studies on N'Dama and Zebu cattle following repeated infections with Trypanosoma congolense. Research in Veterinary Science. 52:292298.

11. Edwards, C.J., Bollongino, R., Scheu, A., Chamberlain, A., Tresset A., Vigne, J-D., Baird, J.F., Larson, G., Ho, S.Y. \& Heupink, T.H. (2007). Mitochondrial DNA analysis shows a Near Eastern Neolithic origin for domestic cattle and no indication of domestication of European 
aurochs. Proceedings of the Royal Society of London B: Biological Sciences. 274:1377-1385.

12. Epstein, H. (1971). The origin of the domestic animals of Africa Volume I. Africana Publishing Corporation. New York. London. Munich. pp. 201-204.

13. Epstein, H. \& Mason, I.L. (1971). Origin of the Domestic Animals of Africa. Holmes \& Meier; NY, USA.

14. Epstein, H. \& Mason, I.L. (1984). Cattle. In: Evolution of Domesticated Animals. ( $1^{\text {st }}$ ed). (Mason I.L. ed) London: Longman. pp 6-97.

15. Eroarome, M.A. (2009). Country Pasture/Forage Resource Profiles. Côte d'Ivoire. FAO, Viale delle Terme di Caracalla, 00153 Rome, Italy. 30p.

16. FAO (2012). Phenotypic characterization of animal genetic resources. Food and Agriculture Organization of United Nations. Rome, Italia. Animal Production and Health Guidelines 11: 144. (available at http://www.fao.org/docrep/015/i2686e00.htm).

17. Hagan, J.K., Apori, S.O., Bsompem, M., Ankobea, G. \& Mawuli, A. (2012). Morphological characteristics of indigenous goats in the coastal savannah and forest eco-zones of Ghana. J. Anim. Sci. Adv., 10: 813-821.

18. Hanotte, O., Bradley, D.G., Ochieng, J.W., Verjee, Y., Hill, E.W., Rege J.E.O. (2002). African pastoralism: genetic imprints of origins and migrations. Science 296:336-339.

19. Hansen, P.J. (2004). Physiological and cellular adaptations of zebu cattle to thermal stress. Anim Reprod Sci. 82:349-360.

20. Hilal, B., El Otman, S., Chentouf, M. \& Boujenane, I. (2013). Morphological characterization of the local goat population "Beni Arouss" In Proc. $8^{\text {th }}$ Int. Seminar of the Sub-Network on Production Systems of the FAO-CICHEAM, 11-13 June 2013, pp. 433437.Tangiers, Morocco, Inter-Regional Cooperative Research and Development Network on Sheep and Goats.

21. ILRI (2002). Safeguarding livestock diversity: The time is now. Annual Report. International Livestock Research Institute; Nairobi, Kenya: 2006.

22. Katongole, J.B., Sebolai, D.B. \& Madinabe (1994). Morphological Characterisation of the Tswana goat. In Small Ruminant Research and Developpement in Africa. Proceeding of the third Biennal Conference of the african Small Ruminant Research Network. UICC, Kampala, Uganda, 43-47.

23. Khan, M., Rhahim, H., Rueff, S., Jalali, S., Saleem, M., Maselli, D., Muhammad, S. \& Wiesmann (2013). Morphological characterization 
of the Azikheli buffalo in Pakistan. Animal Genetic Resources information. (52): 65-70. Doi: 10.1017/82078633613000027.

24. Larrat, R., Camara, A. \& Callumeau, P. (1948). Les bovins N’Dama du Sénégal-Bull. Série Elev. In. Anim., AOF, 1 (4): 15-21.

25. Mani, M., Marichatou, H., Issa, I., Chaïbou, I., Sow, A., Chaïbou, M. \& Sawadogo, J.G. (2014). Caractéristiques phénotypiques de la chèvre du sahel au Niger par des indices de primarité et des paramètres qualitatifs. Animal Genetic Resources information. (54) : 11-19. Doi : 10.1017/82078633613000507.

26. Mattioli, R.C., Bah, M., Kora, S., Cassama, M. \& Clifford, D.J. (1995). Susceptibility to different tick genera in Gambian N'Dama and Gobra Zebu cattle exposed to naturally occurring tick infections. Tropical Animal Health and Production 27:95- 105.

27. Mattioli, R.C., Pandey, V.S., Murray, M. \& Fitzpatrick, J.L. (2000). Immunogenetic influences on tick resistance in African cattle with particular reference to trypanotolerant N'Dama (Bos taurus) and trypanosusceptible Gobra zebu (Bos indicus) cattle. Acta Trop. ;75: 263-277.

28. MIRAH (2003). Rapport national sur l'état des ressources zoogénétiques. Département de la Production Animale du Ministère de la Production Animale et des Ressources Halieutiques, Abidjan, Côte d'Ivoire, 80p.

29. Murray, M., Trail, J.C.M., Davis, C.E. \& Black, S.J. (1984). Genetic resistance to African trypanosomiasis. J. Infect. Dis. 149:311-319.

30. Murray, M., Trail, J.C.M. \& d'Ieteren, G.D.M. (1990). Trypanotolerance in cattle and prospects for the control of trypanosomiasis by selective breeding. O.I.E. Sci. And Tech., Rev., 9: 369-386.

31. Ngamuna, S., d'Ieteren, G.D.M., Itty, P., Leak, S.G.A., Maehl, J.H.H., Minengu, M., Nagda, S.M., Paling, R.W., Rarieya, J.M., Thorpe, W. \& Trail, J.C.M. (1988). Trypanosomiasis in N'Dama cattle under village management in Zaire. In: Livestock Production in Tsetse Affected Areas in Africa. ILCA/ILRAD, Nairobi, Kenya, pp 119-124.

32. N'Goran, K.E., Yapi-Gnaoré, C.V., Fantodji, T.A. \& N'goran, A. (2008). Caractérisation phénotypique et performances zootechniques des vaches laitières en région centre ouest et sud de la Côte d'Ivoire. Arch Zootec, 57 (220): 415-426.

33. N'Goran, K. E., Sokouri, D. P., Yapi-Gnaoré, C.V. \& Fantodji, T.A. (2015). Croisement de la race N'Dama avec les races Abondance et Montbéliarde en zone tropicale humide de Côte d'Ivoire: Caractérisation phénotypique et analyse comparative des croisés pour 
leurs performances laitières en ferme. Agronomie Africaine 27 (1) : 15-26.

34. N'Goran, K.E., Gbodjo, Z.L., M'Bari, K.B., Loukou, N.E., Doumbia, L., \& Dosso, R. (2017). Reproduction and production comparative analysis of $\mathrm{F}_{1} \mathrm{~N}^{\prime}$ Dama $\mathrm{x}$ Montbéliarde and Holstein in the dairy station of Yamoussoukro in Côte d'Ivoire. International journal of Recent Scientific Research. Vol. 8, Issue, 6, pp. 17821-17827. http://www.recentscientific.com.

Doi: http://dx.doi.org/10.243227/ijrsr.2017.0806.0427.

35. Okeyo Mwai, Olivier Hanotte, Young-Jun Kwon, \& Seoae Cho (2015). African Indigenous Cattle: Unique Genetic Resources in a Rapidly Changing World. Asian-Australas J Anim Sci. 2015 Jul; 28(7): 911921. doi: 10.5713/ajas.15.0002R.

36. Pagot, J. (1985). L'Elevage en Pays Tropicaux. GP Maisonneuve Larose et ACCT, ed, Paris (France), 526p.

37. Rege, J.E.O. \& Tawah, C.L. (1999). The state of African cattle genetic resources II. Geographical distribution characteristics and uses of present day breeds and strains. Animal Genetic Resources information. (26): 1-26.

38. Roberts, C.J. \& Gray, A.R. (1973). Studies on trypanosome-resistant cattle. II. The effect of trypanosomiasis on N'Dama, Muturu and Zebu cattle. Trop Anim Health Prod. 5:220-233.

39. Rokosz' Mieczyslaw (1995). "History of the Aurochs (Bos Taurus Primigenius) in Poland". Animal Genetics Resources Information (Food and Agriculture Organization) 16: 5-12. Doi: 10.1017/S101423900004582.

40. Salem, M., Rahim, I., Jalali, S., Rueff, H., Khan, M., Maselli, D., Wiesmann, U. \& Muhammad, S. (2013). Morphological characterization of Achai cattle in sedentary and trashumant system in Pakistan. Animal Genetic Ressources information: (52): 83-90. Doi : 10.1017/8207863361200080X.

41. Sokouri, D.P., Loukou N.E., Yapi-Gnaoré, C.V., Mondeil, F. \& Gnangbé, F. (2007). Caractérisation phénotypique des bovins à viande (Bos taurus et Bos indicus) au centre (Bouaké) et au nord (Korhogo) de la Côte d'Ivoire. Animal Genetic Resources Information (AGRI). $40: 43-53$.

42. Sokouri, D.P., Yapi-Gnaoré, C.V., N'Guetta, A.S.P., Loukou, N.E., Kouao, B.J., Touré, G., Sangaré A. \& Kouassi, A. (2009). Utilisation et gestion des races taurines locales sous la pression des croisements avec les zébus dans les regions Centre et Nord de la Côte d'Ivoire. Journal of Animal \& Plant Sciences. Voi.5, Issue 2 : 456-465. http://www.biosciences.elewa.org/JAPS. 
43. Stock, F. \& Gifford-Gonzalez, D. (2013). Genetics and African cattle domestication. Afr Archaeol Rev. 30:51-72.

44. Touré, S.M. \& Hoste, H.C. (1987). Bétail trypanotolérant et trypanotolérance. Revue des connaissances. Bull Séanc Acad Sci Outre-Mer, 32 (1986-3) : 369-411.

45. Viennot, M. (1983). Etude pédologique de la région de Touba (Côte d'Ivoire). Carte des unités morpho-pédologiques et des paysages morpho-pédologiques. Feuille Touba. Note explicative $\mathrm{N} \circ 88$. ORSTOM, Paris. 100p. 